\title{
MAUDE ABBOTT
}

Members of the Cardiac Society learned with deep regret of the death of Dr. Maude Abbott, our only woman honorary member, on September 3, 1940.

She was born in Quebec in 1869 and passed her medical life almost entirely in her native country of Canada. Some years were spent in Scotland, where she qualified in 1897; and from 1923 to 1925 she was Professor of Pathology and Bacteriology at the Women's Medical College in Philadelphia. But her medical career was bound up with McGill University, Montreal, where she served as Curator of the Pathological Museum from 1899, as Lecturer in Pathology from 1912 to 1923, and as Assistant Professor of Medical Research from 1925. Her University recognized her faithful service and high achievement by conferring upon her the honorary degree of M.D., and later of LL.D.

In congenital malformations of the heart she found her life interest, and in 1905 Sir William Osler invited her to write on Congenital Cardiac Disease for his System of Medicine. From that time patient and methodical research on this subject became her ruling passion, and established Maude Abbott as the greatest authority in the world on congenital heart disease. The main basis of her work was an exhaustive and critical study of pathological specimens wherever these had been reported or were to be found, with the ultimate purpose of clinical classification and recognition. The results are to be found in her contributions to Blumer's Bedside Diagnosis, and to Nelson's Loose-Leaf Medicine, and notably in the monumental Atlas of Congenital Cardiac Disease published by the American Heart Association in 1936. It is an outstanding feature of Maude Abbott's work that, beginning firmly on the pathological footing, she raised from what was merely a disconnected and unproductive series of cases a distinct and defined branch of cardiology - and this with a facility of diagnosis now, of course, rapidly increasing because of the special help afforded by electrocardiography and radiography.

In 1913, the Seventeenth International Congress of Medicine was assembled in London, and Dr. Maude Abbott had the pleasure of attending a meeting of the International Association of Medical Museums, which was founded largely owing to her initiative and of which she became the permanent secretary. Again she found in Osler a powerful friend and supporter; and it was characteristic that she made herself responsible as editor for the classified and annotated bibliography of Sir William Osler's publications, printed in Montreal. From 1907 to 1938 she was editor of the Journal of Technical Methods and Bulletin of the International Association of Medical Museums.

Maude Abbott was a woman of simple and unaffected charm, easy to know I. 
and pleasant to meet. The expression of her eyes was eager and searching, yet soft with an engaging kindliness. She travelled a good deal and made friends wherever she went. Unspoiled by success, she was happy and content with the knowledge that she had completed her great and complicated task. She had applied that clean-cut and orderly mind in clearing up the cardiac malformations of the child, and she will be remembered as a pioneer " not content with fragments and scattered pieces of Truth."

John Parkinson. 